\title{
The distribution of vertical leaves and leaves biomass on ten mangrove species at Ngurah Rai Forest Park, Denpasar, Bali, Indonesia
}

\author{
I PUTU GEDE ARDHANA ${ }^{1, \bullet}$, I M.G.S. RIMBAWAN ${ }^{2}$, PUJO NUR CAHYO ${ }^{2}$, YUYUN FITRIANI ${ }^{3}$, SISKA ROHANI \\ ${ }^{1}$ Department of Biology, Faculty of Mathematics and Natural Sciences, Universitas Udayana. Jl. Raya Kampus Unud, Jimbaran, Kuta Selatan, \\ Badung 80361, Bali, Indonesia. Tel./fax+62-361-701954, •email: crescentbali@indo.net.id \\ ${ }^{2}$ Climate Change Control and Forest Fire and Land Border of The Region of Java, Bali, and Nusa Tenggara. Jl. Bypass Ngurah Rai Km. 21, \\ Suwung Kauh, Pemogan, Denpasar 80221, Bali, Indonesia \\ ${ }^{3}$ Faculty of Agriculture, Universitas Udayana. Jl. Raya Kampus Unud, Jimbaran, Kuta Selatan, Badung 80361, Bali, Indonesia \\ ${ }^{4}$ Program of Environmental Science, School of Graduates, Universitas Udayana. Jl. P.B. Sudirman, Denpasar 80232, Bali, Indonesia
}

Manuscript received: 12 December 2017. Revision accepted: 27 April 2018.

\begin{abstract}
Ardhana IPG, Rimbawan IMGS., Cahyo PN, Fitriani Y, Rohani S. 2018. The distribution of vertical leaves and leaves biomass on ten mangrove species at Ngurah Rai Forest Park, Denpasar, Bali, Indonesia. Biodiversitas 19: 918-926. The distribution of vertical leaves and leaves biomass which forms the mangrove crown divides into three parts, namely the top part, the middle part, and the bottom part. Total amount leaves on any parts are highly variable depending on height of each species. The relationship between the height of tree with the crown thickness depended on total leaves of each crown on each species as well as the relationship between the total leaves biomass of each crown on each species, with the height and volume of tree stems, also has variation on each mangrove species. Author examined the relationship between the photosynthetic organs with non-photosynthetic organs, especially on stems in each species. The high total amount of leaves and large total amount leaves biomass deeply is depended on diameter and growth height which are presented in the form of stem volumes. On the relationship between the photosynthetic organs and non-photosynthetic organs on each mangrove species, also has been examined. The higher total amount of leaves or the total amount of leaves biomass largely depended on the stem volume of mangroves. This indicates that the production of photosynthetic organ either in the form of the total amount of leaves or the total amount of leaves biomass serve to support growth of the stem mangrove trees (height of stem, diameter of stem and volume of stem).
\end{abstract}

Keywords: Adaptation, multi-layer, mangrove species, vertical leaves and leaves biomass distributions

\section{INTRODUCTION}

This study includes a form of adaptation of tree architecture both in the tropics and in the temperate regions. This architectural form is heavily influenced by the sunlight received by the tree crown from the top of the tree to the lowest canopy of the tree. Form of tree architecture adaptation is in the form of monolayer and multilayer. Of the 10 mangrove species exhibit a multilayer adaptive form with different distribution of leaves from the top of the crown, middle and bottom. Meanwhile, if the monolayer form of the number of leaf distribution shows the number of leaves from top to bottom of the crown is uniform because it gets a little sunlight under the shade of tree stands in this study is not found form of monolayer architecture adaptation. The adaptative architecture of trees in tropical forests has been examined in successive (Chazdon 1986; Givnish 1982). The research on adaptative architecture of trees on mangrove forest in tropical does not exist yet, but has done a lot of research on the distribution of carbon stocks, and productivity of mangrove forest (see Camacho et al. 2011; Fatoyinbo and Simard 2013; Sitoe et al. 2014; Taberima et al. 2014; Sahu et al. 2016; Njana et al. 2017). The research on adaptive architecture of tree in the temperate regions has also been done (see Horn 1971; Nicola and Pickets 1983; Ehlesinger and Kenneths 1986;
Ardhana et al. 1988). These researchers related with adaptive architecture of trees such as the distribution of leaves pattern, the leaves biomass and the absorption of carbon. The distribution of leaves pattern, leaves biomass, absorption of carbon with growth of the stem are major causes of the highlight of environmental constraints, such as potential total amount leaves at the bottom, middle and top layer of crown to absorb sunlight (Chazdon 1985, 1986). The adaptive architecture of trees has possibility which forms the response of adaptive group of leaves in unit trees (Waller and Steingracher 1986); adaptive photosynthesis (Givnish 1982); the role of carbon balance and the branching pattern in growth of trees (Schulze et al. 1986). Those become major causes of stress for environmental constraint that occurs in the part of crown trees. If overstorey does not have full of sunlight, the growth of crown trees is varied layers such as bottom, middle and top layers.

The effective distribution of leaves or leaves biomass is very important for the survival of living leaves in all species of trees. The distribution and growth of crown structure in overstory and understory trees are commonly subject to various constraints such as limited light condition in the crown trees (Chazdon 1985, 1986; Taberima et al. 2014). The adaptive architecture of trees may form collective response of modular unit in the plants 
(Waller and Steingraeber 1986; Taberima et al. 2014) for the common environmental condition of leaves in the layer of crown of overstory species. The research about the distribution of leaves and the leaves biomass are associated with absorption of carbon in the atmosphere at both the photosynthesis (leaves) organs and non-photosynthesis (stems) organs, but for mangrove species, research is rare.

The purpose of this research is to compare the distribution pattern of vertical leaves and leaves biomass on ten mangrove species, and to understand the relationship between the photosynthesis organ and non-photosynthesis organs on each mangrove species.

\section{MATERIALS AND METHODS}

This study was carried out in the secondary forest of mangrove as former fishpond farms at Ngurah Rai Forest Park, Denpasar, Bali, Indonesia (115 $9^{\circ}-115^{0} 14^{\prime} \mathrm{E}, 8^{0} 42^{\prime}$ $\left.8^{0} 49^{\prime} \mathrm{S}\right) 3.5 \mathrm{~km}$ east of Denpasar City. The sphere of temperature ranges from $22^{\circ} \mathrm{C}-28^{\circ} \mathrm{C}$ and annual precipitation are $1,800 \mathrm{~mm}$, with climate type of $\mathrm{E}$ (Schmidt Fergusson). A study plot which has size of $20 \mathrm{~m}$ x $20 \mathrm{~m}$ was used in this Forest Park. The soil conditions are poor as former fishpond farms and the soil profile does not show the developed mineral soil layers (a layer).

The crown of any tree species was divided into three parts of crown layers which are part of top layer, middle and bottom layer. In the plot, the light condition from the sun is state of being open. All species belong to the overstory species, were identified and noted, in order to measure species density. But the leaves distribution on the top layer, middle and bottom layer were different, and most distribution of leaves is part of multi-layer species. But in the bottom crown part, highest total amount leaves were showed, and also the amount of biomass content and carbon became high. Comparison between tree height and crown thickness with the total amount of carbon which absorbed by leaves as photosynthesis organs showed that there was closely relation to any carbon content of nonphotosynthesis organs, especially the tree height of stems. In any species, the relation between amounts of leaves with tree height also varied with the value of $r$ could be seen in Figure 1, so those were showing the positive relation.

The distribution of leaves, leaves biomass, and any carbon content of leaves were studied for ten dominant overstory species among others Rhizophora mucronata, $R$. apiculata, R. stylosa, Bruguiera gymnorrhiza, Ceriops tagal, Sonneratia alba, Avicennia alba, Lumnitzera racemosa, Xylocarpus moluccensis and Phempis acidula. The sum of the sample trees can be seen in Table 1, the sample of every tree species is divided vertically into three parts of layers, namely the top, the middle and the bottom part of layers, and total amount leaves in each part were calculated over the period of June to August 2016.

Biomass of photosynthesis organs and nonphotosynthesis organs of ten mangrove species has been calculated. Non-photosynthesis organs were obtained from diameter, tree height and the form value in each stem of sample species were multiplied by the value of 0.7 , then calculated the volume of stems with the formula:

$$
\mathrm{V}=\pi \mathrm{r}^{2} \mathrm{x} \mathrm{T} \times 0.7 \text { (Asy’ari et al. 2012) }
$$

Where:

V : Volume

$\mathrm{T}:$ Tree height $(\mathrm{cm})$

While to obtain the wood density of stem, it was used the wood density from the table of Global Wood Density Data Base (Zanne et al. 2009; ITTO 2013), which has The International-Standard. But especially for $P$. acidula species, the formula cannot be found from the global wood density table. Hence to calculate the wood density we used this formula:

$$
\mathrm{BJ}=\mathrm{BK}(\mathrm{g}) / \mathrm{V}\left(\mathrm{cm}^{3}\right) \text { (Daryadi et al. 1976) }
$$

$$
\begin{aligned}
& \text { Where: } \\
& \text { BJ : Wood density }\left(\mathrm{g} \mathrm{cm}^{-3}\right) \\
& \text { BK : Wood dry weight }(\mathrm{g}) \\
& \text { V : Wood volume }\left(\mathrm{cm}^{3}\right)
\end{aligned}
$$

In order to measure wood density, we cut the part of around branches with branch length up to $20 \mathrm{~cm}$ and measured the diameter of pieces of branches, total wood fresh weight and wood fresh weight sample regions (10 $\mathrm{cm})$, and for wood dry weight sample were cut into $(10 \mathrm{~cm})$ in length, and these were over dried with temperature $100^{\circ} \mathrm{C}$ within 48 hours of constant weight. To calculate leaves biomass was used with the formula:

$\mathrm{BO}=\mathrm{Bks} \times \mathrm{Bbt} / \mathrm{Bbs}(\mathrm{SNI} 2011)$

Where:

$\mathrm{BO}:$ organic matter (leaves biomass) $\rightarrow$ (leaf biomass) (g)

Bbt : leaf fresh weight total $(\mathrm{g})$

Bks : leaf dry weight sample $(\mathrm{g})$

Bbs : leaf fresh weight sample $(\mathrm{g})$

To find stem biomass the allometry equation was used which was introduced by Chave et al. (2005). This equation is the basis of the allometry used by Chave et al. (2005) with dividing humid climate zone (1500-4000) $\mathrm{mm}$ year $^{-1}$, adjusted to the study sites having annual precipitation is $1800 \mathrm{~mm}$ :

$$
\mathrm{BAP}=0.0509 \times \rho \mathrm{D}^{2} \mathrm{H}(\text { Chave et al. 2005) }
$$

Where:

BAP : biomass tree stems $(\mathrm{g} / \mathrm{stem}) \rightarrow$ tree stems biomass (g/stem)

$$
\begin{array}{ll}
\rho & : \text { wood density }\left(\mathrm{g} / \mathrm{cm}^{3}\right) \\
\mathrm{D} & : \text { diameter tree stem }(\mathrm{cm}) \\
\mathrm{H} & : \text { the tree height }(\mathrm{cm})
\end{array}
$$

To find the amount of carbon content, the tree stems biomass was multiplied by the value of 0.47 according to SNI (2011). In each species of trees the parameter of leaves consisting of the total amount leaves, the total fresh weight, 
total fresh weight of sample, total dry weight, dry weight of samples, and total amount of leaves area was calculated. The leaves area were measured in the laboratory of the Faculty of Animal Husbandry, Udayana University, Bali, Indonesia using a leaf electric meters.

The relation between amounts of leaves, leaves biomass, and value of carbon with the tree height has been analyzed for all species. The regression value to all species can be seen in Table 2. The comparison between tree height with crown thickness and comparison between the total amount of wood carbon and leaves carbon presented in the form of Figure 5.

\section{RESULTS AND DISCUSSION}

The species composition of mangrove species is shown in Table 1 which found in the study plot.

Table 1. Species composition and wood density $\left(\mathrm{g} / \mathrm{cm}^{3}\right)$ of mangrove tree species in the plot $(80<\mathrm{H} \leq 410) \mathrm{cm}$

\begin{tabular}{|c|c|c|c|c|}
\hline Species & Family & $\begin{array}{c}\text { Wood density } \\
\mathrm{g} / \mathrm{cm}^{3}\end{array}$ & $\begin{array}{c}\text { Individuals } \\
\left(\text { per } 400 \mathrm{~m}^{2}\right)\end{array}$ & $\begin{array}{c}\text { Total of } \\
\text { Samples trees }\end{array}$ \\
\hline Rhizophora mucronata & Rhizophoraceae & 0.79 & 4 & 3 \\
\hline Rhizophora apiculata & Rhizophoraceae & 0.86 & 4 & 3 \\
\hline Rhizophora stylosa & Rhizophoraceae & 0.91 & 4 & 3 \\
\hline Bruguiera gymnorrhiza & Rhizophoraceae & 0.73 & 5 & 3 \\
\hline Ceriops tagal & Rhizophoraceae & 0.88 & 6 & 3 \\
\hline Sonneratia alba & Sonneratiaceae & 0.65 & 3 & 3 \\
\hline Lumnitzera racemosa & Combretaceae & 0.74 & 3 & 3 \\
\hline Xylocarpus moluccensis & Malvaceae & 0.51 & 3 & 3 \\
\hline Phempis acidula & Lyctroceae & 0.00 & 3 & 3 \\
\hline Aegiceras corniculatum & Myrsinaceae & 0.51 & 2 & - \\
\hline Excoecaria agallocha & Euphorbiaceae & 0.726 & 1 & - \\
\hline Derris trifoliata & Leguminosae & - & 1 & - \\
\hline Acrostichum aureum & Pteridaceae & - & 1 & - \\
\hline Sesuvium portulacastrum & Aizoaceae & - & 3 & - \\
\hline
\end{tabular}

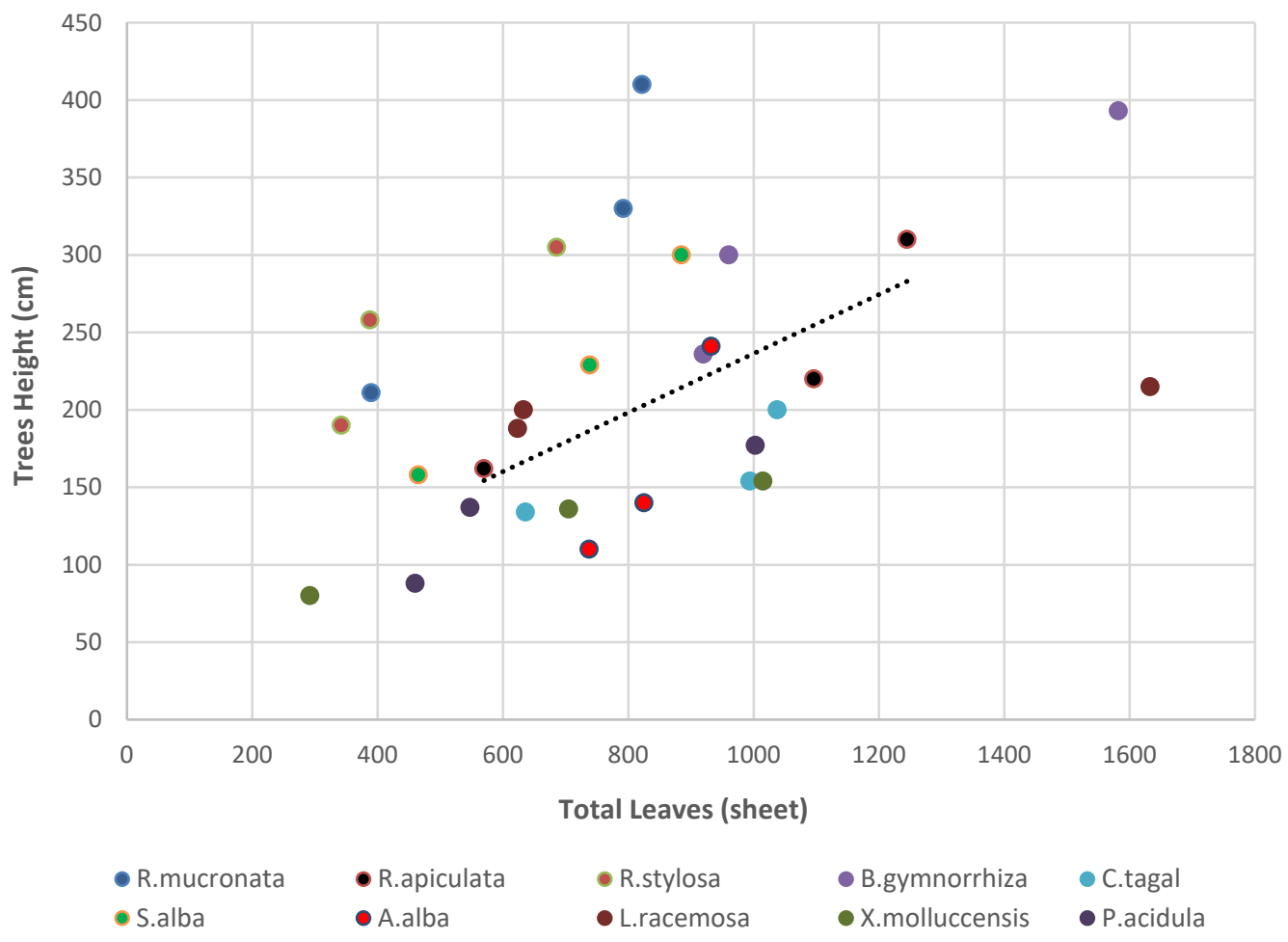

Figure 1. Regression of the leaves number (sheet) and trees height $(\mathrm{cm})$ 


\section{The relationship between the number of leaves and the tree height}

The relationship between the number of leaves and tree height for ten mangrove species can be seen in Figure 1.

In each species, total amount of leaves per tree increased with tree height from smallest tree up to highest tree. The total amount of leaves increase, then followed by increase in tree height. In every mangrove species sampled, leaf vertical distribution shows the leaf expansion phase with the regression equation of all mangrove species can be seen in (Table 2).

The height of the trees from of varies sample each individual showing the total number of leaves increased as the development phase of leaves so that the number of leaves for all species is still relatively growing as shown in Figure 1.

The result of these research indicated that most leaves were supported by the high light intensity (full of sunlight), because all mangrove species belong to the category of overstory species.

For each mangrove species the leaves characteristic of were defined with the data about the total area of leaves $\left(\mathrm{cm}^{2}\right)$, total fresh weight of leaves $(\mathrm{g})$ and the total amount of leaves (sheet), specific leaf area $\left(\mathrm{cm}^{2} / \mathrm{g}\right)$, leaf area $\left(\mathrm{cm}^{2}\right)$ and fresh leaf weight $(\mathrm{g})$ in each species could be seen in Table 3 and 4.

The total amount of leaves which were varied in each species ranged from 471.90 sheets for $R$. stylosa and 1154.23 sheets to B. gymnorrhiza (Table 5 ).

\section{Vertical distribution of leaves biomass and leaves carbon in each mangrove species}

The vertical analysis of leaves distribution, biomass and leaf carbon content were carried out for ten mangrove species. The analysis showed that the vertical distribution of leaves varied for all tree species in Figure 2. Comparison of total leaves, leaves biomass, and leaves carbon among species can be seen in Figure 3.

The crown thickness is the height of top crown to bottom crown in each tree species, where some leaves occur. The analysis showed that in each species the leaves were classified into multilayer type. The comparison between tree height and the thickness of crown increased with the addition of another crown that may be caused by the number of leaves in leaf increasing phase. The crown thickness can be seen in Figure 4 with their standard deviations (Table 6).

\section{The relationship between the photosynthesis organ and the non-photosynthesis organ}

The vertical distribution of non-photosynthesis organs (stems) and photosynthesis organ (leaves) were presented in the forms of tree height, leaves biomass and absorption of carbon, and showed the same form although in each species have different sizes of trees.

The comparison between photosynthesis organs and non-photosynthesis organs either in the form of crown thickness as the total amount of leaves, leaves biomass and carbon of leaves and the form of tree height, as the wood biomass and wood carbon absorption, were presented in the form of Figure 5.

The ratio between photosynthesis organs (leaves carbon) and non-photosynthesis organs (wood carbon) could influence to productivity of biomass and carbon per unit in each species. The ratio of leaves carbon (F) against wood carbon as the non-photosynthesis organs (C) has been made in leaf-increasing phase. Each species is having the ratio of $\mathrm{C} / \mathrm{F}$ varying as shown in Table 7.

Table 2. Regression value of leaf number (sheet) and tree height (cm)

\begin{tabular}{lll}
\hline Species & Equation & $\mathbf{R}^{2}$ \\
\hline R. mucronata & $\mathrm{y}=0.3901 \mathrm{x}+56.424$ & $\mathrm{R}^{2}=0.883$ \\
R. apiculata & $\mathrm{y}=0.1905 \mathrm{x}+45.825$ & $\mathrm{R}^{2}=0.8215$ \\
R. stylosa & $\mathrm{y}=0.2709 \mathrm{x}+123.18$ & $\mathrm{R}^{2}=0.7653$ \\
B. gymnorrhiza & $\mathrm{y}=0.1988 \mathrm{x}+80.18$ & $\mathrm{R}^{2}=0.8743$ \\
C. tagal & $\mathrm{y}=0.1224 \mathrm{x}+53.835$ & $\mathrm{R}^{2}=0.6353$ \\
S. alba & $\mathrm{y}=0.3282 \mathrm{x}+0.5284$ & $\mathrm{R}^{2}=0.9704$ \\
A. alba & $\mathrm{y}=0.6828 \mathrm{x}-404.26$ & $\mathrm{R}^{2}=0.9412$ \\
L. racemosa & $\mathrm{y}=0.021 \mathrm{x}+180.79$ & $\mathrm{R}^{2}=0.8096$ \\
X. moluccensis & $\mathrm{y}=0.1041 \mathrm{x}+53.488$ & $\mathrm{R}^{2}=0.9581$ \\
P. acidula & $\mathrm{y}=0.1389 \mathrm{x}+40.917$ & $\mathrm{R}^{2}=0.8252$ \\
\hline
\end{tabular}

Table 3. Total leaves/tree (sheet), average leaf fresh weight/tree $(\mathrm{g})$, and average leaf area/tree $\left(\mathrm{cm}^{2}\right)$ in leaf-increasing phase

\begin{tabular}{lccccc}
\hline \multicolumn{1}{c}{ Species } & $\begin{array}{c}\text { Total } \\
\text { sample } \\
\text { trees }\end{array}$ & $\begin{array}{c}\text { Ranges } \\
\text { of } \\
\text { height } \\
\text { (cm) }\end{array}$ & $\begin{array}{c}\text { Total } \\
\text { Leaves/tree }\end{array}$ & $\begin{array}{c}\text { Average } \\
\text { leaf fresh } \\
\text { weight/tree } \\
(\mathbf{g})\end{array}$ & $\begin{array}{c}\text { Average } \\
\text { Leaf } \\
\text { area/tree } \\
\left.\mathbf{( c m}^{2}\right)\end{array}$ \\
\hline R. mucronata & 3 & $211-410$ & 668.00 & 0.0178 & 5.07 \\
R. apiculata & 3 & $162-310$ & 970.23 & 0.0085 & 3.33 \\
R. stylosa & 3 & $190-305$ & 471.90 & 0.0143 & 2.73 \\
B. gymnorrhiza & 3 & $236-393$ & 1154.23 & 0.0100 & 3.81 \\
C. tagal & 3 & $134-200$ & 889.40 & 0.0846 & 2.20 \\
S. alba & 3 & $158-300$ & 696.23 & 0.0242 & 2.51 \\
A. alba & 3 & $110-241$ & 831.77 & 0.0253 & 1.33 \\
L. racemosa & 3 & $188-215$ & 963.03 & 0.0223 & 0.89 \\
X. moluccensis & 3 & $80-154$ & 670.67 & 0.0579 & 2.13 \\
P. acidula & 3 & $88-177$ & 670.17 & 0.0610 & 1.24 \\
\hline
\end{tabular}

Table 4. Specific to leaf area $\left(\mathrm{cm}^{2} / \mathrm{g}\right)$

\begin{tabular}{lccc}
\hline Species & $\begin{array}{c}\text { Leaf area } \\
\left(\mathbf{c m}^{\mathbf{2}}\right)\end{array}$ & $\begin{array}{c}\text { Leaf fresh } \\
\text { weight } \\
(\mathbf{g} / \mathbf{s h e e t})\end{array}$ & $\begin{array}{c}\text { Specific of } \\
\text { leaf area } \\
\text { (sheet) } \\
\left(\mathbf{c m}^{\mathbf{2} / \mathbf{g})}\right.\end{array}$ \\
\hline R. mucronata & 5.07 & 0.0178 & 284.831 \\
R. apiculata & 3.33 & 0.0085 & 391.765 \\
R. stylosa & 2.73 & 0.0143 & 190.909 \\
B. gymnorrhiza & 3.81 & 0.0100 & 381.000 \\
C. tagal & 2.20 & 0.0846 & 26.005 \\
S. alba & 2.51 & 0.0242 & 103.719 \\
A. alba & 1.33 & 0.0253 & 52.569 \\
L. racemosa & 0.89 & 0.0223 & 39.910 \\
X. moluccensis & 2.13 & 0.0579 & 36.788 \\
P. acidula & 1.24 & 0.0610 & 20.328 \\
\hline
\end{tabular}


Table 5. Total leaves (sheet), for each mangrove tree

\begin{tabular}{|c|c|c|c|c|c|c|c|}
\hline \multirow{2}{*}{ Species } & \multicolumn{4}{|c|}{ Total leaves (sheet) } & \multirow{2}{*}{$\mathbf{X}$} & \multirow[b]{2}{*}{$\bar{X}$} & \multirow{2}{*}{ Total leaves/ trees } \\
\hline & & I & II & III & & & \\
\hline \multirow[t]{3}{*}{ R. mucronata } & Top crown & 136 & 265 & 38 & 439.00 & 146.33 & 668.00 \\
\hline & Middle crown & 291.9 & 226.1 & 171 & 689.00 & 229.67 & \\
\hline & Bottom crown & 394 & 301 & 181 & 876.00 & 292.00 & \\
\hline \multirow{3}{*}{ R. apiculata } & Top crown & 298 & 139 & 92 & 529.00 & 176.33 & 970.23 \\
\hline & Middle crown & 286 & 141.7 & 230 & 657.70 & 219.23 & \\
\hline & Bottom crown & 512 & 289 & 923 & 1.724 .00 & 574.67 & \\
\hline \multirow[t]{3}{*}{ R. stylosa } & Top crown & 83 & 72 & 60 & 215.00 & 71.67 & 471.90 \\
\hline & Middle crown & 147.8 & 184.9 & 124 & 456.70 & 152.23 & \\
\hline & Bottom crown & 157 & 429 & 158 & 744.00 & 248.00 & \\
\hline \multirow{3}{*}{ B. gymnorrhiza } & Top crown & 443 & 112 & 243 & 798.00 & 266.00 & 1154.23 \\
\hline & Middle crown & 375.3 & 100.5 & 275.6 & 751.40 & 250.47 & \\
\hline & Bottom crown & 764 & 707.3 & 442 & 1.913 .30 & 637.77 & \\
\hline \multirow[t]{3}{*}{ C. tagal } & Top crown & 153 & 100 & 174 & 427.00 & 142.33 & 889.40 \\
\hline & Middle crown & 370 & 313.3 & 160 & 843.30 & 281.10 & \\
\hline & Bottom crown & 514.8 & 581 & 302.1 & 1.397 .90 & 465.97 & \\
\hline \multirow[t]{3}{*}{ S. alba } & Top crown & 100 & 108 & 96 & 304.00 & 101.33 & 696.23 \\
\hline & Middle crown & 142.6 & 169 & 114.1 & 425.70 & 141.90 & \\
\hline & Bottom crown & 496 & 608 & 255 & 1.359 .00 & 453.00 & \\
\hline \multirow{3}{*}{ A. alba } & Top crown & 132 & 131 & 127 & 390.00 & 130.00 & 831.77 \\
\hline & Middle crown & 253.2 & 158.4 & 112.7 & 524.30 & 174.77 & \\
\hline & Bottom crown & 440 & 643 & 498 & 1.581 .00 & 527.00 & \\
\hline \multirow[t]{3}{*}{ L. racemosa } & Top crown & 221 & 102 & 112 & 435.00 & 145.00 & 963.03 \\
\hline & Middle crown & 148.8 & 176.3 & 562 & 887.10 & 295.70 & \\
\hline & Bottom crown & 263 & 345.2 & 958.8 & 1.567 .00 & 522.33 & \\
\hline \multirow[t]{3}{*}{ X. moluccensis } & Top crown & 132 & 39 & 84 & 255.00 & 85.00 & 670.67 \\
\hline & Middle crown & 283 & 52 & 183 & 518.00 & 172.67 & \\
\hline & Bottom crown & 600 & 201 & 438 & 1.239 .00 & 413.00 & \\
\hline \multirow[t]{3}{*}{ P. acidula } & Top crown & 106 & 38 & 39 & 183.00 & 61.00 & 670.17 \\
\hline & Middle crown & 193 & 94 & 131 & 418.00 & 139.33 & \\
\hline & Bottom crown & 248.5 & 871 & 290 & 1.409 .50 & 469.83 & \\
\hline
\end{tabular}

Note: $\mathrm{X}=$ Total leaves (sheet); $\bar{X}=$ Average of leaves (sheet).

Table 6. Standard deviation of tree height and crown thickness

\begin{tabular}{|c|c|c|c|c|}
\hline Species & $\begin{array}{c}\bar{X} \\
\text { Trees height }(\mathrm{cm})\end{array}$ & SD trees height & $\begin{array}{c}\bar{X} \\
\text { Crown thickness }(\mathrm{cm})\end{array}$ & SD Crown thickness \\
\hline R. mucronata & 317.00 & $317.00 \pm 211.33$ & 258.67 & $258.67 \pm 172.44$ \\
\hline R. apiculata & 230.67 & $230.67 \pm 153.78$ & 201.00 & $201.00 \pm 134.00$ \\
\hline R. stylosa & 251.00 & $251.00 \pm 167.33$ & 212.67 & $212.67 \pm 141.78$ \\
\hline B. gymnorrhiza & 309.67 & $309.67 \pm 206.44$ & 285.33 & $285.33 \pm 190.22$ \\
\hline C. tagal & 162.67 & $162.67 \pm 108.44$ & 142.67 & $142.67 \pm 95.11$ \\
\hline S. alba & 229.00 & $229.00 \pm 152.67$ & 183.00 & $183.00 \pm 122.00$ \\
\hline A. alba & 163.67 & $163.67 \pm 109.11$ & 125.33 & $125.33 \pm 83.56$ \\
\hline L. racemosa & 201.00 & $201.00 \pm 134.00$ & 196.00 & $196.00 \pm 130.67$ \\
\hline X. moluccensis & 123.33 & $123.33 \pm 82.22$ & 104.67 & $104.67 \pm 69.78$ \\
\hline P. acidula & 134.00 & $134.00 \pm 89.33$ & 126.00 & $126.00 \pm 84.00$ \\
\hline
\end{tabular}

Note: $\mathrm{SD}=$ Standard deviation; $\bar{X}=$ Average

Table 7. Ratio of wood carbon (C) (g) and leaves carbon (F) (g)

\begin{tabular}{|c|c|c|c|c|c|c|c|}
\hline Species & $\begin{array}{c}\text { Trees } \\
\text { height }(\mathrm{cm})\end{array}$ & $\begin{array}{c}\text { Wood } \\
\text { biomass (g) }\end{array}$ & $\begin{array}{c}\text { Wood } \\
\text { carbon }(\mathrm{C})(\mathrm{g}) \\
\end{array}$ & $\begin{array}{c}\text { Crown } \\
\text { thickness }(\mathrm{cm})\end{array}$ & $\begin{array}{c}\text { Leaves } \\
\text { biomass (g) }\end{array}$ & $\begin{array}{c}\text { Leaves } \\
\text { carbon (F) (g) }\end{array}$ & Ratio C/F \\
\hline R. mucronata & 317.00 & 180.92 & 84.92 & 258.67 & 62.08 & 29.18 & 2.91 \\
\hline R. apiculata & 230.67 & 53.69 & 25.23 & 201.00 & 51.12 & 24.03 & 1.05 \\
\hline R. stylosa & 251.00 & 61.40 & 38.86 & 212.67 & 47.87 & 22.5 & 1.73 \\
\hline B. gymnorrhiza & 309.67 & 134.85 & 63.38 & 285.33 & 65.75 & 30.87 & 2.05 \\
\hline C. tagal & 162.67 & 117.88 & 55.40 & 142.67 & 20.94 & 9.84 & 5.63 \\
\hline S. alba & 229.00 & 135.04 & 63.47 & 183.00 & 24.01 & 11.29 & 5.62 \\
\hline A. alba & 163.67. & 15.01 & 7.06 & 125.33 & 22.07 & 10.37 & 0.68 \\
\hline L. racemosa & 201.00 & 199.72 & 93.87 & 196.00 & 20.97 & 9.86 & 9.52 \\
\hline X. moluccensis & 123.33 & 45.38 & 21.33 & 104.67 & 19.48 & 9.15 & 2.33 \\
\hline P. acidula & 134.00 & 0.00 & 0.00 & 126.00 & 11.3 & 5.31 & 0.00 \\
\hline
\end{tabular}



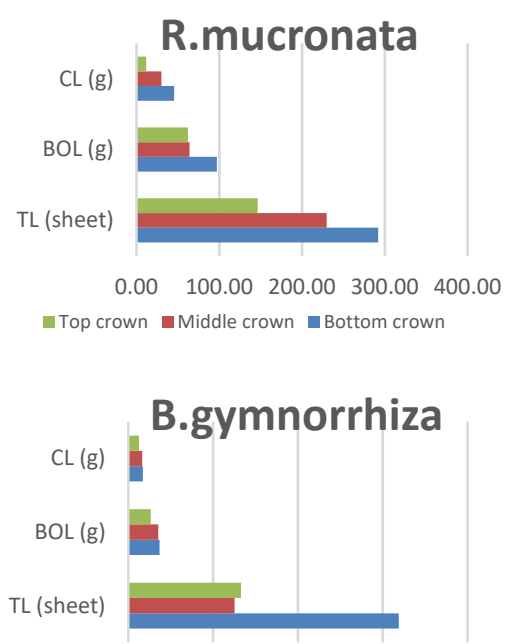

$0.00 \quad 200.00 \quad 400.00 \quad 600.00 \quad 800.00$ - Top crown Middle crown $\square$ Bottom crown
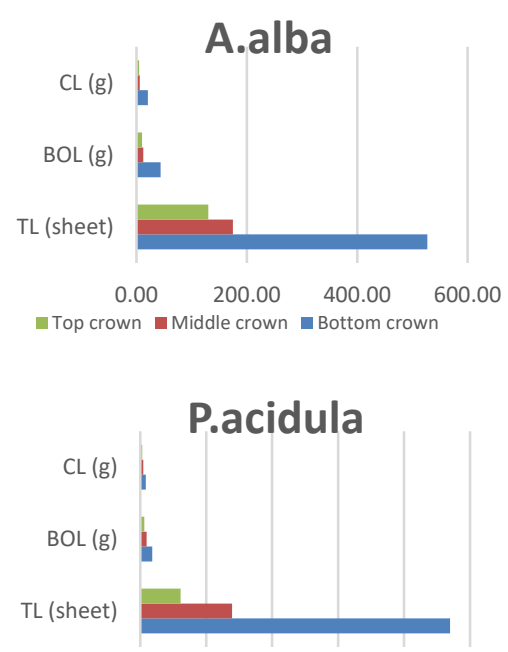

0.00100 .00200 .00300 .00400 .00500 .00 Top crown Middle crown $\square$ Bottom crown
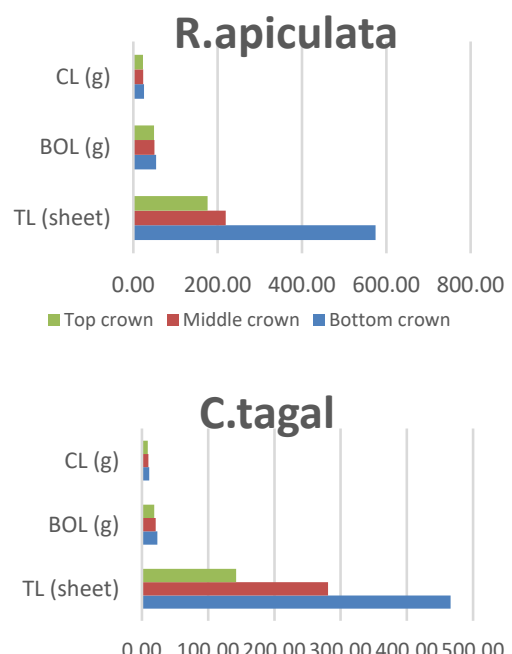

- Top crown $\square$ Middle crown $\square$ Bottom crown

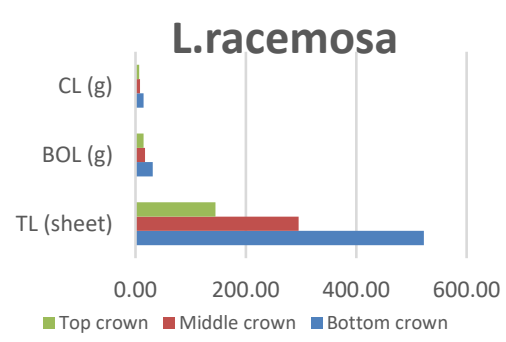

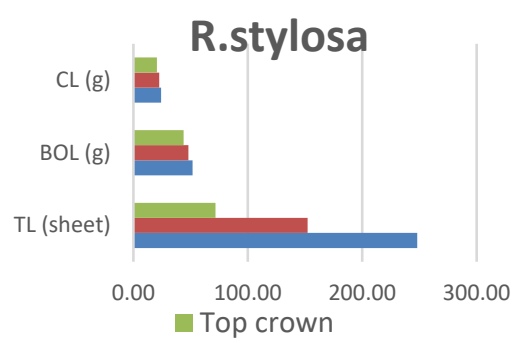

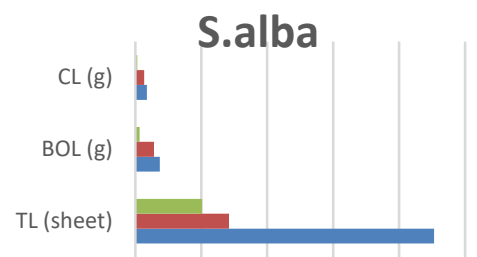

0.00100 .00200 .00300 .00400 .00500 .00 - Top crown $\square$ Middle crown $\square$ Bottom crown

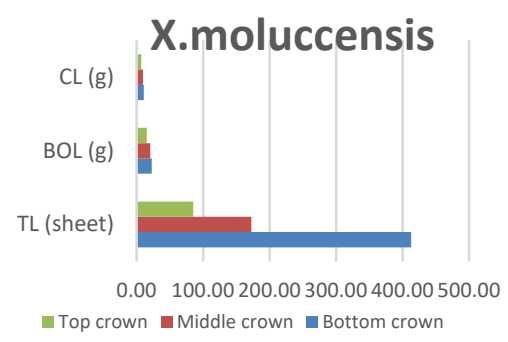

Figure 2. The distribution of total leaves (TL) (sheet), leaves biomass $\left(\mathrm{BO}_{\mathrm{L}}\right)(\mathrm{g})$, and leaves carbon $\left(\mathrm{C}_{\mathrm{L}}\right)(\mathrm{g})$

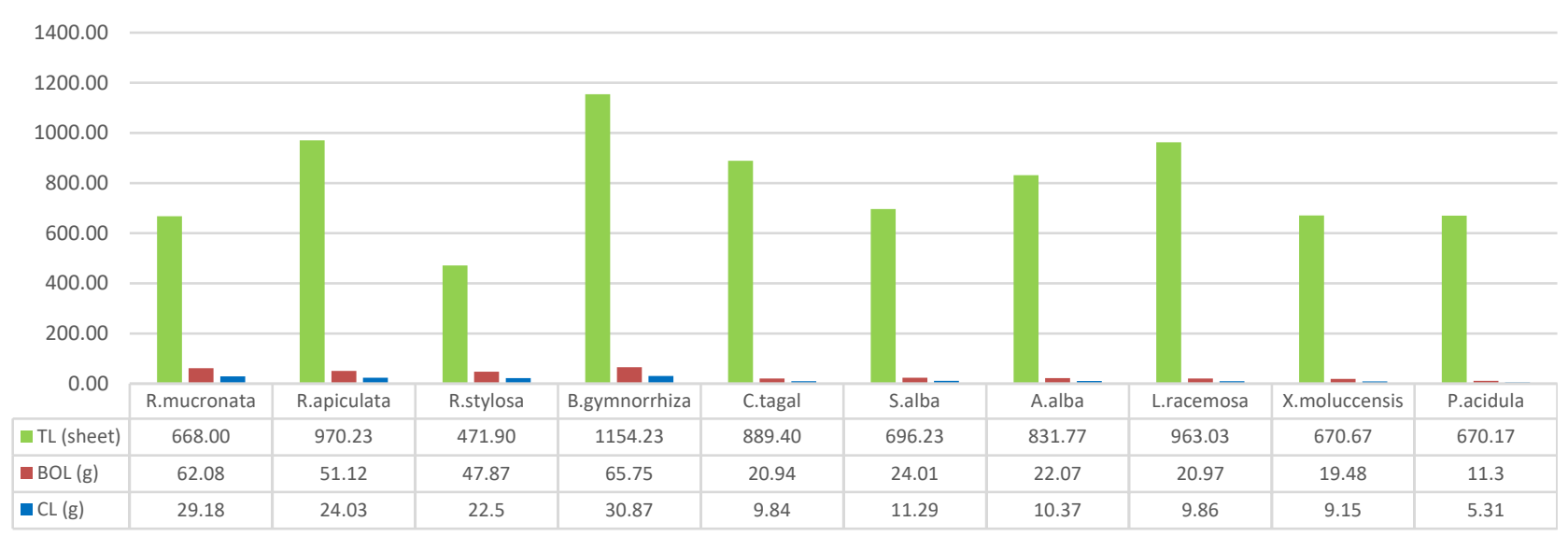

Figure 3. Comparison of total leaves (TL) (sheet), leaves biomass $\left(\mathrm{BO}_{\mathrm{L}}\right)(\mathrm{g})$, and leaves carbon $\left(\mathrm{C}_{\mathrm{L}}\right)(\mathrm{g})$ 


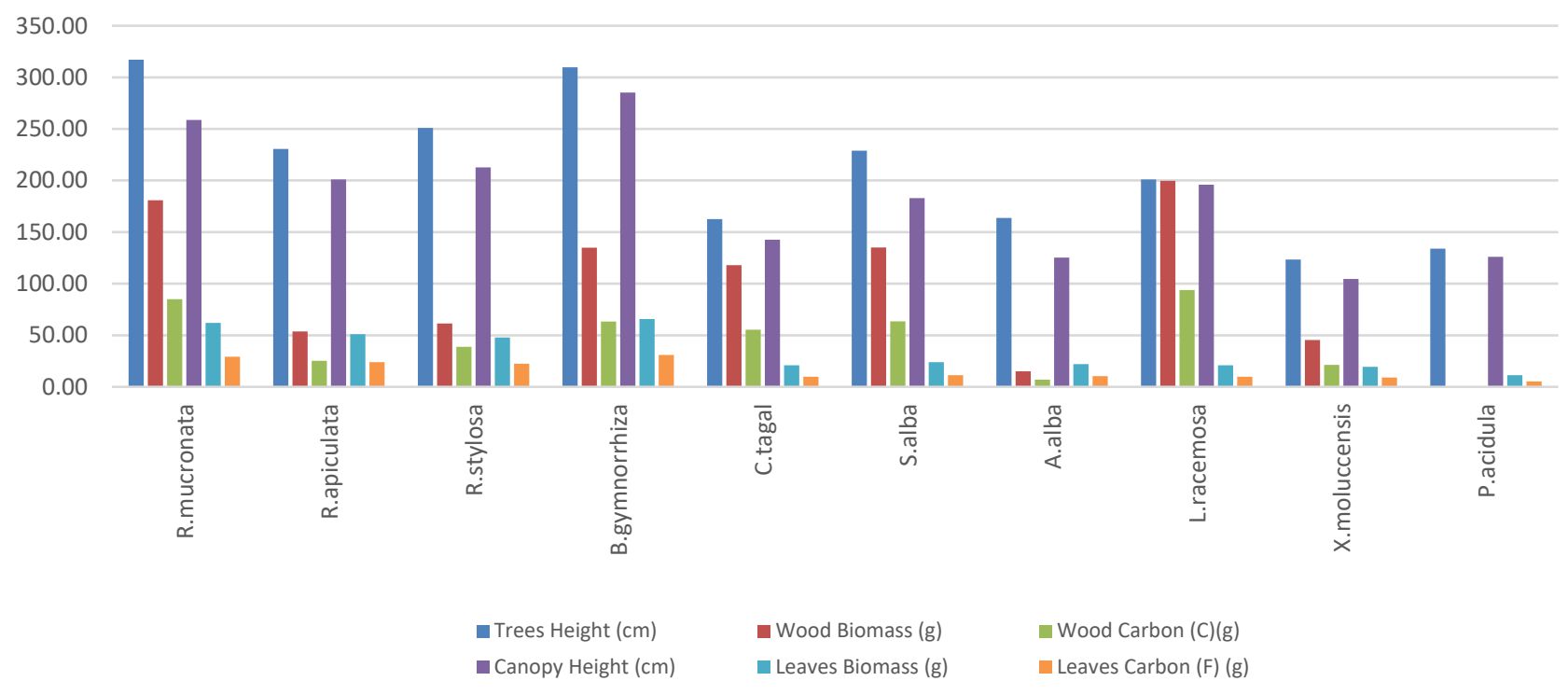

Figure 5. The comparison of trees height, wood biomass, wood carbon, and crown thickness, leaves biomass, leaves carbon

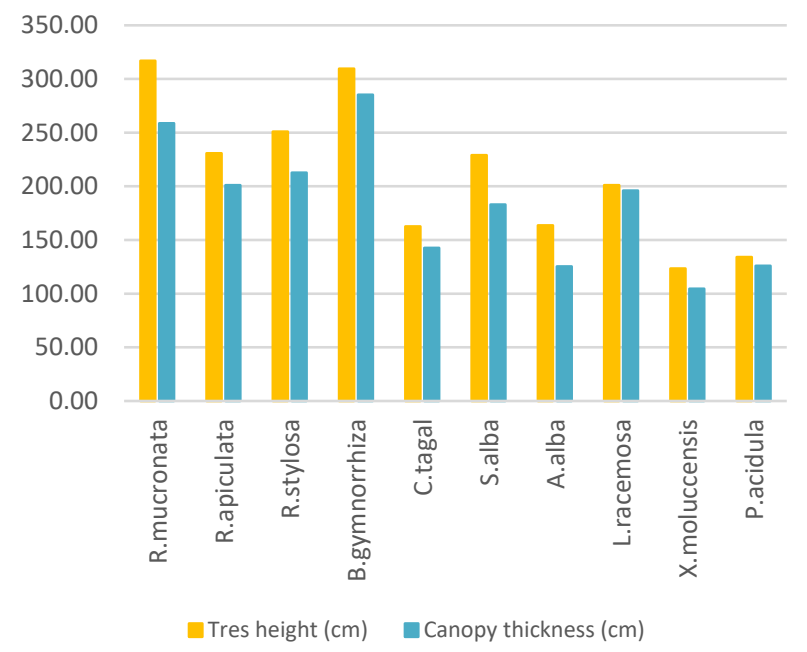

Figure 4. The comparison of tree height and crown thickness

\section{Discussion}

The relationship between the total amount of leaves and tree height in ten mangrove species showed that each species still at the leaf increasing phase. In the leaf increasing phase, tree height was followed by the total amount of leaves that formed crown layers at the top, middle and bottom part of each tree. In each species, the total amount of leaves did not constant, but continues to grow as seen in Figure 1 with regressions that evaluated positive value as shown in Table 2 . This condition possibly was caused by the tree age of the species, because these trees were still young (approximately about 3 years of age), and also perhaps due to the land conditions that were poor, dominated by the texture of sandy soil. Moreover, upper layer of soil did not yet form a layer with low total density of trees at 16 species in a plot size of $20 \mathrm{~m} \times 20 \mathrm{~m}$.

Moller (1947) argued that leaves biomass would increase gradually with age. Kittredge (1944) also proposed that the leaves biomass increase with age and begins to be constant at 60-90 years of age. Hatinya et al. (1966) stated that leaves biomass increase with increasing of site index. In general, high leaves biomass is found in a good site condition.

The total amount of leaves varied from species. The larger or smaller the leaf weight in each species depends on the specific size of the leaf area, the larger the specific leaf area depends on the leaf area and the leaf weight of each tree species as shown in Table 3 and 4 . Table 4 indicated that the Rhizophora apiculata showed the highest specific leaf area among others, namely $391.765 \mathrm{~cm}^{2} / \mathrm{g}$ because it had the highest leaf area $\left(3.33 \mathrm{~cm}^{2}\right)$ high with leaf weight only $0.0085 \mathrm{~g}$. Likewise, $P$. acidula had leaf area of 1.24 $\mathrm{cm}^{2}$ with the leaf weight of $0.0610 \mathrm{~g}$ showing a smallest specific leaf area of about $20.328 \mathrm{~cm}^{2} / \mathrm{g}$.

Horn (1971) divides into two types of adaptive crown that affect the development of the crown, the first development is a multilayer leaf distribution type and the second is a monolayer type which is a leaf development character formed from the overlap of young leaves on an open and closed canopy layer. In the leaf-increasing phase type, the evergreen species have a multi-layer leaf distribution (Horn 1971). It is predicted that the number of leaves will be greater than the type of mono-layer species. In addition, the distribution of vertical leaves can be calculated by the difference in leaf number on each layer of the tree crown.

The shape of the tree crown is attributed of the development of the shoots at the tip of tree as well as that the branch buds, which can be seen in the vertical distribution of the leaves and organs supporting the stem 
and tree branches. Waller and Steingraeber (1986), found that the adaptive architecture of tree form collective response of modular unit in the plants. The leaves are concentrated in the horizontal layer where each leaf effectively spreads and occupies the gap, to obtain sunlight. It appears that all mangrove species used as samples are concentrated in the multi-layer of the crown. The thickness of the crown is higher than the mono-layer type species.

The ratio between the amount of leaf carbon $(\mathrm{F})$ and wood carbon (C) increases with tree height. Givnish (1982) found that the proportion of organs support the number of leaves such as stems, branches, and twigs is increasing very rapidly as the growth of tree height increases. The resulting net production is not only from the average of photosynthesis and respiration per unit of biomass, but also are influenced by the number of leaves to support nonphotosynthesis organ of stem biomass, branches and twigs of trees. Dry weight of leaves as photosynthesis organ varies within the ratio of leaf weight and leaf area. As a result, the dry weight of the material produced during the growing season is dependent on the amount of dry weight difference occurring at the beginning of the growing season, namely on average photosynthesis and respiration results, distribution of new photosynthesis organ on different types of leaf distribution, specific leaf area and mean difference of dead organ which cause loss weight.

In conclusion, the research on the adaptation of tree architecture in mangrove forests is still very limited, but has been widely used both in tropical forests and in subtropical forest areas. The results showed that the relationship between tree height and number in leaves of ten mangrove species was positive with the value of $(r)$ regression varying from the smallest value $\left(\mathrm{R}^{2}=0.6353\right)$ owned by $C$. tagal and the highest value $\left(\mathrm{R}^{2}=0.9704\right)$ by Sonneratia alba. It can be concluded that the total number of leaves per tree is still relatively increased with the increase of tree height from the smallest tree to the highest tree and still in the leaf increasing phase. The total number of leaves varies within each species between 471.90 sheets for Rhizophora stylosa and 1154.23 sheets for the $B$. gymnorrhiza species. Comparison of the number of leaves, leaves biomass, and leaves carbon shows the same distribution, starting at the top of the crown, to the middle and bottom, shows the development of crown units represented the increasing phase of either for each species, and can be classified into multilayer leaf distribution types.

The amount of leaf biomass and leaf carbon content in each species depends on leaf area $\left(\mathrm{cm}^{2}\right)$, leaf weight (g/sheet) and specific leaf area. R. apiculata leaf showing the largest value of specific leaf area, is $391.765 \mathrm{~cm}^{2} / \mathrm{g}$ and the smallest at $P$. acidula with the value of $20.238 \mathrm{~cm}^{2} / \mathrm{g}$. The ratio between photosynthetic organ and nonphotosynthetic organ is influenced by the biomass productivity of carbon leaves per leaf unit in each species. This ratio creates a continuous leaf increasing phase, and each species has a variable $\mathrm{C} / \mathrm{F}$ ratio, the largest lies in Lumnitzera racemosa with $\mathrm{C} / \mathrm{F}$ is 9.52 , and the lowest in Avicennia alba with $\mathrm{C} / \mathrm{F}$ is 0.68 . This means that the greater the value of $\mathrm{C} / \mathrm{F}$, leaf unit or leaf carbon can form larger stems of trees and vice versa.

\section{ACKNOWLEDGEMENTS}

We thank the International Seminar committee of the Society for Indonesian Biodiversity, which has given us the opportunity to attend in this seminar and also thank the Head of Climate Change Mitigation and Forest Fire and Land Region of Java, Bali, and Nusa Tenggara that has assisted us in providing useful information.

\section{REFERENCES}

Ardhana IPG, Takeda H, Sakimoto M, Tsutsumi T. 1988. The vertical foliage distributions of six understory tree species in a Chamaecyparis obtusa Endl. Forest. Structure and Function Trees. Springer Verlag, Berlin.

Camacho LD, Gevana DT, Carandang AP, Camacho SC, Combalicer EA, Rebugio LL, Youn TC. 2011. Tree biomas and carbon stock of a community-managed mangrove forest in Bohol, Philippines. For Sci Technol 7 (4): 161-167.

Chave J, Andalo C, Brown S, Cairns MA, Chambers JQ, Eamus D, Folster H, Fromard F, Higuchi N, Kira T, Lescure J-P, Nelson BW, Ogawa H, Puig H, Riera B, Yamakura T. 2005. Tree allometry and improved estimation of carbon stocks and balance in tropical forests. Oecologia 145 (1): 87-99.

Chazdon RL. 1985. Leaf display, canopy structure and light interception of two understory palm species. Am J Bot 72: 1493-1502

Chazdon RL. 1986. The cost of leaf support in understory palms. Economy versus safety. Am Nat 127: 9-30

Daryadi L, Meulenhoff LMW, Soediono SY, Soemawidjaja U, al-Rasyid H, Silitonga T, Wiroatmodjo P, Martadiwangsa ES, Soekandi, Madyana T, Mardyono, Baddrudin TA, Soeparmo, Kadir K, Djokosoetarmo, Sidabutar M. 1976. Vademecum Kehutanan Indonesia. Direktorat Jenderal Kehutanan, Departemen Pertanian, Jakarta. [Indonesian]

Fatoyinbo TE, Simard M. 2013. Height and biomass of mangroves in Africa from ICESat/GLAS and SRTM. Intl J Rem Sens 34 (2): 668681.

Givnish TJ. 1982. On the adaptive significance of leaf height in forest herbs. Am Nat 20: 353-381

Hatinya K, Tochiaki K, Narita T. 1966. Analysis of growth in natural forests of Pinus densiflora: relationships between site quality and growth. Trans 76th Mtg Jap For Soc (1965): 161-162.

Horn HS. 1971. The adaptive geometry of trees. Princeton University Press, Princeton, USA.

ITTO. 2013. Penyusunan baseline data pengelolaan ekosistem mangrove di Pulau Bintan. ITTO Project RED-PD 064/11 Rev. 2 (F). Direktorat Jenderal Bina Pengelolaan Daerah Aliran Sungai dan Perhutanan Sosial Kementerian Kehutanan, Jakarta. [Indonesian]

Kittredge, 1944. Estimation of the amount of foliage of trees and stands. Journal forestry. 42:905-912

Moller CM. 1947. The effect of thinning, age, and site on foliage, increment, and loss of dry matter. Journal of forestry. 45:393-404

Nicola A, Pickett STA. 1983. The adaptive architecture of shrub canopies: leaf display and biomass allocation in relation to light environment. New Phytol 93: 301-310

Njana MA, Zahabu E, Malimbwi RE. 2017. Carbon stocks and productivity of mangrove forests in Tanzania. Southern Forests. DOI: 10.2989/20702620.2017.1334314

Sahu SC, Kumar M, Ravindranath NH. 2016. Carbon stock in natural and planted mangrove forests of Mahanadi mangrove Wetland, East Coast of India. Curr Sci 110 (12): 2334-2341.

Schulze ED, Kuppers M, Matyssek R. 1986. The role of carbon balance and branching pattern in the growth of woody species. In: Givinish TJ (ed) On the Economy of Plant Form and Function. Cambridge University Press, New York.

Sitoe AA, Mandlate LJC, Guedes BS. 2014. Biomass and carbon stocks of Sofala Bay Mangrove Forest. Forests 5 (8): 1967-1981.

SNI. 2011. SNI No. 7724: 2011 Pengukuran dan penghitungan cadangan karbon pengukuran lapangan Untuk penaksiran cadangan karbon hutan (Ground-based forest carbon accounting). Badan Standarisasi Nasional, Jakarta. [Indonesian] 
Taberima S, Nugroho YD, Murdiyarso D. 2014. The distribution of carbon stock in selected. mangrove ecosystem of Wetlands Papua: Bintuni, Teminabuan, and Timika, Eastern Indonesia. Internasional Conference on Chemical, Environment \& Biological Sciences. Kuala Lumpur, Malaysia.

Waller DM, Steingraeber DA. 1986. Branching and modular growth. In Jackson JBC, Buss LW, Cook PE (eds.) Population Biology and
Evolution of Clonal Organisms. Yale University Press, New Haven, USA

Zanne AE, Lopez-Gonzalez G, Coomes DA, Ilic J, Jansen S, Lewis SL, Miller RB, Swenson NG, Wiemann MC, Chave J. 2009. Data from: towards a worldwide wood economics spectrum. Dryad Digital Repository 2009. DOI: 10.5061/dryad.234. 